\title{
HUBUNGAN ANTARA MOTIVASI DENGAN HASIL BELAJAR MATEMATIKA PADA POKOK BAHASAN PERSAMAAN DAN PERTIDAKSAMAAN LINIER SIWA KELAS X APK SMK YPM 3 TAMAN
}

\author{
Kartini \\ (SMK YPM 3 Taman) \\ kartiniaza@yahoo.com
}

\begin{abstract}
This research is motivated by the fact of learning outcomes and a low level of mastery students were most likely caused by low motivation to learn is possessed by students. Motivation itself is based, the environment of the school and family environment. The design of this study used a correlational research design. This study aims to determine whether there is a relationship between motivation and learning outcomes on the subject of math equations and linear inequalities. Instrument of data collection using questionnaires to obtain data of motivation to learn, and test methods for obtaining data learning outcomes. The data were analyzed using correlation techniques poduct moment. The population in this study were students, the students of class X APK SMK YPM 3 Taman Sidoarjo were 112 students, while the sample is taken by random sampling as much as $35 \%$ of the 40 students. The research results obtained $r_{\text {value }}$ correlation coefficient $=0.379$, later than $r_{\text {table }}$ at significant level of $5 \%$ and $\mathrm{N}=40$ is 0.312 Turns $r_{\text {value }}$ greater than $r_{\text {table }}$. It can be concluded that there is a relationship between motivation and learning outcomes on the subject of math equations and linear inequalities.
\end{abstract}

Keywords: learning motivation, learning outcomes, linear equations and inequalities

\section{PENDAHULUAN}

Masa depan bangsa Indonesia berada di tangan generasi muda. Berkualitas atau tidaknya generasi muda salah satunya bergantung pada kualitas pendidikan. Oleh karena itu, pendidikan memegang peranan penting dalam mempersiapkan sumber daya manusia yang berkualitas dan kompeten dalam perkembangan ilmu pengetahuan dan teknologi, sehingga dampaknya dapat dilihat pada pembangunan bangsa. Hal ini relevan dengan tujuan pendidikan seperti yang tertuang dalam Undang Undang No. 20 Tahun 2003 tentang tujuan pendidikan nasional Bab II Pasal 3 yang berbunyi:

"Pendidikan nasional bertujuan mengembangkan kemampuan dan membentuk watak serta peradaban bangsa yang bermartabat dalam rangka mencerdaskan bangsa, bertujuan untuk berkembangnya potensi peserta didik agar menjadi manusia yang beriman dan bertakwa kepada Tuhan YME, berakhlak mulia, sehat, berilmu, cakap, kreatif, mandiri dan menjadi warga negara yang demokratis serta bertanggung jawab"

Dengan adanya Undang-Undang tersebut, pendidikan harus dikelola dengan baik yaitu melalui pembelajaran yang baik dan tepat. Sampai saat ini, berbagai upaya telah dilakukan oleh pemerintah untuk meningkatkan kualitas pendidikan demi tercapainya tujuan pendidikan nasional. Akan tetapi pada kenyataannya hasil belajar yang didapatkan oleh siswa masih jauh dari harapan dan belum sesuai dengan tujuan pendidikan nasional. Seperti halnya hasil belajar pada mata pelajaran matematika, hasilnya masih kurang memuaskan. Didasarkan data UNESCO, mutu pendidikan matematika di Indonesia berada pada peringkat 34 dari 38 negara yang diamati. Data lain yang menunjukkan rendahnya prestasi matematika siswa Indonesia dapat dilihat dari hasil survei Pusat Statistik Internasional untuk Pendidikan (National Center for Education in Statistics, 2003) terhadap 41 negara dalam pembelajaran matematika, di mana Indonesia mendapatkan peringkat ke 39 di bawah Thailand dan 
Uruguay. Pada saat ini matematika merupakan salah satu pelajaranyang penting dan masuk dalam UAN (Ujian Akhir Nasional). Matematika merupakan salah satu ilmu dasar yang berperan dalam ilmu pengetahuan dan teknologi (IPTEK). Implikasinya Matematika wajib diberikan kepada siswa disamping disiplin ilmu lainnya. Pelajaran Matematika dimulai dari tingkat Sekolah Dasar (SD) sampai dengan perguruan tinggi. Kenyataan yang terjadi di dalam pembelajaran matematika disekolah saat ini adalah banyaknya persepsi negatif dari siswa bahwa mempelajari pelajaran matematika itu membosankan, tidak menarik, sukar, sulit dan tidak tampak kaitannya dalam kehidupan sehari-hari. Paradigma inilah yang menjadikan hilangnya motivasi belajar matematika dan menjadi kendala dalam keberhasilan proses pembelajaran matematika.

Rendahnya pemahaman siswa tentang pelajaran matematika kemungkinan besar/adalah rendahnya motivasi belajar yang dimiliki oleh siswa. Motivasi ini didasarkan dirinya sendiri, lingkungan sekolah maupun dari lingkungan keluarga. Dalam proses pembelajaran, siswa yang memiliki motivasi yang tinggi dalam mempelajari matematika, akan melakukan kegiatan lebih cepat dibandingkan dengan siswa yang kurang termotivasi dalam mempelajari matematika. Siswa yang memiliki motivasi yang tinggi dalam mempelajari matematika maka hasil belajar yang diraih juga akan lebih baik. Siswa yang menganggap pelajaran matematika adalah salah satu pelajaran yang susah dipahami mengakibatkan siswa tersebut cenderung malas dalam mengikuti pembelajaran matematika. Akibatnya lainnnya adalah siswa kurang memerhatikan pelajaran yang disampaikan sehingga hasil belajar masih kurang baik dan belum memenuhi standar yang berlaku di sekolah.

Berdasarkan hasil ulangan umum bersama, nilai matematika pada materi Sistem Bilangan Riil yang merupakan materi prasyarat persamaan dan pertidaksamaan linier hanya sekitar $60 \%$ siswa yang dapat mencapai ketuntasan minimal. Jika materi prasyarat hasil kurang maksimal maka materi selanjutnya akan mengalami kesulitan. Penulis menduga yang menyebabkan hal tersebut karena kurangnya motivasi yang berasal dari diri sendiri dan dari luar. Faktor dari luar salah satu satunya adalah kondisi kelas yang sempit dengan jumlah siswa yang besar yaitu lebih dari 50 siswa. SMK YPM 3 Taman merupakan lokasi penelitian untuk mengetahui motivasi siswa pada materi persamaan dan pertidaksamaan linier karena penulis sedang melaksanakan PPL 2.

Berdasarkan uraian latar belakang di atas, maka penulis mengadakan penelitian dengan judul "Hubungan Antara Motivasi Dengan hasil Belajar Matematika Pada Pokok Bahasan Persamaan dan Pertidaksamaan Linier Siwa Kelas X APK SMK YPM 3 Taman”. Tujuan penelitian ini adalah untuk mengetahui hubungan antara motivasi dengan hasil belajar matematika pada pokok bahasan persamaan dan pertidaksamaan linier siswa kelas X APK di SMK YPM 3 Taman.

\section{METODE PENELITIAN}

Rancangan penelitian merupakan tahapan proses yang diperlukan dalam merencanakan dan pelaksanaan penelitian. Rancangan penelitian pada dasarnya merupakan proses pemikiran dan penentuan secara matang akan hal-hal yang akan dilakukan dan dijadikan pedoman selama pelaksanaan penelitian.

Dalam penelitian ini digunakan rancangan penelitian korelasional. Penelitian koresional adalah penelitian yang akan melihat hubungan antara dua variabel. Yang terdiri dari satu variabel bebas dan satu variabel terikat. Menurut Sugiono (2008:42) dapat digambarkan seperti gambar berikut.

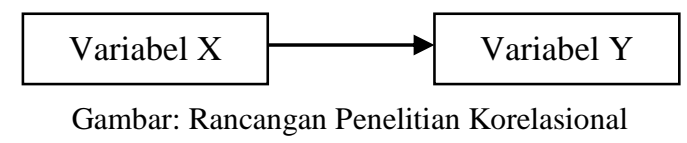

Variabel $\mathrm{X}$ adalah variabel bebas pada penelitian ini yaitu motivasi belajar, sedangkan variabel $\mathrm{Y}$ pada penelitian ini adalah variabel terikat yaitu: hasil belajar siswa setelah mengikuti proses pembelajaran.

\section{Populasi dan sampel}

Populasi menurut Sugiyono (2008:80) adalah wilayah generalisasi yang terdiri atas objek / subjek yang 
mempunyai kualitas dan karakteristik tertentu yang ditetapkan oleh peneliti untuk dipelajari dan kemudian ditarik kesimpulannya. Dalam penelitian ini, populasinya adalah seluruh siswa kelas X APK SMK YPM 3 Taman. Jumlah seluruhsiswa kelas X APK SMK YPM 3 taman 112 siswi.

Menurut Arikunto (2006:131) sampel adalah sebagian atau wakil populasi yang diteliti. Dalam pengambilan sampel peneliti menggunakan teknik random sampling yaitu sejumlah $35 \%$ dari 112 siswa $=40$ siswa.

\section{Metode Pengumpulan Data}

Metode pengumpulan data menurut Arikunto (2006:219) adalah cara yang diapakai dalam mengumpulkan data. Dalam penelitian ini metode pengumpulan data yang digunakan ada dua, yaitu metode angket untuk mengukur motivasi belajar dan metode tes untuk data tentang hasil belajar. Berikut ini akan dijelaskan masing-masing metode pengumpulan data yang digunakan dalam penelitian ini.

\section{Metode Angket}

Menurut Arikunto (2006:151), mengemukakan bahwa "angket adalah sejumlah pertanyaan yang digunakan unuk memperoleh informasi dari responden dalam arti laporan tentang pribadi atau hal-hal lain yang diketahui". Angket yang digunakan dalam penelitian ini adalah angket tertutup dan langsung kepada responden, dengan pertimbangan sebagai berikut.

a. Alternatif jawaban telah tersedia sehingga responden lebih mudah dalam memberikan jawaban.

b. Pertanyaan-pertanyaan dapat untuk mengkasifikasi para responden

c. Dalam menganalisis data penulis tidak mengalami banyak kesulitan.

\section{Metode Tes}

Menurut Arikunto (2006:150) tes adalah serentetan pertanyaan atau latihan serta alat lain yang digunakan untuk mengukur keterampilan, sikap, inteligensi, kemampuan atau bakat yang dimiliki individu atau kelompok.
Tes yang digunakan dalam penelitian ini adalah tes subjektif, dengan pertimbangan untuk mengetahui dan mengukur pemahaman anak. Junlah soal sebanyak 10 soal. Waktu untuk mengerjakan tes subjektif adalah 90 menit.

\section{Metode Analisis Data}

Metode analisis data adalah cara yang dipergunakan untuk menganalisa data yang telah dikumpulkan dari hasil penelitian guna menguji kebenaran hipotesa yang diambil penelitiDalam penelitian ini penulis menggunakan analisis statistik dengan teknik korelasi product moment. Data yang diperoleh dari penelitian berwujud angka-angka kuantitatif, sehingga dengan cara tersebut dapat dianalisa sebagaimana mestinya dengan data yang penulis kumpulkan kemudian dianalisa dengan terlebih dahulu disusun, diolah, dan dianalisis, selanjutnya disimpulkan.

Analisa data pada penelitian ini, penulis menggunakan rumus korelasi product moment menurut Sugiyono (2008:183) sebagai berikut:

$$
r x y=\frac{n \sum X Y-\left(\sum X\right)\left(\sum Y\right)}{\sqrt{\left\{n \sum X^{2}-\left(\sum X\right)^{2}\right\}\left\{n \sum Y^{2}-\left(\sum Y\right)^{2}\right\}}}
$$

Keterangan:

$\mathrm{r}=$ Korelasi $\mathrm{X}$ dengan $\mathrm{Y}$

$\mathrm{n}=$ Jumlah responden

$\mathrm{X}=$ Motivasi belajar siswa

$\mathrm{Y}=$ Hasil belajar

Selanjutnya dalam pengujian hipotesis dilakukan langkah-langkah sebagai berikut:

1. Menentukan hipotesis

Ho : $\rho_{1}=\rho_{2}$, tidak terdapat hubungan antara motivasi belajar dengan hasil belajar pada pokok bahasan persamaan dan pertidaksamaan linier siswa kelas X APK di SMK YPM 3 Taman

$H a: \rho_{1} \neq \rho_{2}$ terdapat hubungan antara motivasi belajar dengan hasil belajar pada pokok bahasan persamaan dan pertidaksamaan linier siswa kelas $\mathrm{X}$ APK di SMK YPM 3 Taman

2. Menentukan taraf signifikan $\alpha=0,05$ atau $5 \%$ 
Kartini : Hubungan Antara Motivasi Dengan Hasil Belajar Matematika Pada Pokok Bahasan Persamaan dan Pertidaksamaan Linier Siwa Kelas X APK SMK YPM 3 Taman

3. Menghitung $r$

4. Menentukan kriteria pengujian Ho dengan menggunakan Kriteria perolak Ho

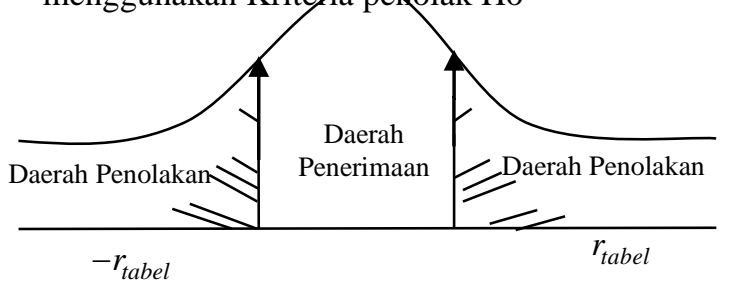

Gambar kriteria penerimaan $\mathrm{H}_{0}$

$H_{o}$ diterima jika $:-r_{\text {tabel }}<r_{\text {hitung }}<r_{\text {tabel }}$

$H_{o}$ ditolak jika : $r_{\text {hitung }}<-r_{\text {tabel }}$ atau $r_{\text {hitung }}>r_{\text {tabel }}$

\section{HASIL DAN PEMBAHASAN}

Analisa data dalam penelitian ini dimaksudkan untuk menguji hipotesis penelitian yang telah dijelaskan dalam penelitian ini. Analisa data dalam penelitian ini meliputi: pengujian hipotesis dengan langkah sebagai berikut:

1. Hipotesis penelitian

$H o: \rho_{1}=\rho_{2}$ tidak terdapat hubungan antara motivasi belajar dengan hasil belajar pada pokok bahasan persamaan dan pertidaksamaan linier siswa kelas X APK di SMK YPM 3 Taman

$H a: \rho_{1} \neq \rho_{2}$ terdapat hubungan antara motivasi belajar dengan hasil belajar pada pokok bahasan persamaan dan pertidaksamaan linier siswa kelas $\mathrm{X}$ APK di SMK YPM 3 Taman

2. Menentukan Taraf signifikan $\alpha=0,05$ atau 5\%

3. Menghitung $\mathrm{r}$ dengan menggunakan rumus Korelasi Product Moment

$$
r x y=\frac{n \sum X Y-\left(\sum X\right)\left(\sum Y\right)}{\sqrt{\left\{n \sum X^{2}-\left(\sum X\right)^{2}\right\}\left\{n \sum Y^{2}-\left(\sum Y\right)^{2}\right\}}}
$$

4. Kriteria Penolakan Ho

Tolak Ho jika $r_{\text {hitung }}>r_{\text {tabel }}$. Dari hasil perhitungan di atas diketahui $r_{\text {hitung }}=0,379>r_{\text {tabel }}=0,312$ dengan taraf signifikan $5 \%$ dan $\mathrm{N}=40$. Maka Ho (hipotesis nihil) yang berbunyi: tidak terdapat hubungan antara motivasi belajar dengan hasil belajar pada pokok bahasan persamaan dan pertidaksamaan linier siswa kelas X APK di SMK YPM 3 Taman ditolak.

5. Kesimpulan

$r_{\text {hitung }}=0.379>r_{\text {tabel }}$ maka Ho ditolak artinya Ha (hipotesis angka) yang berbunyi : terdapat hubungan antara motivasi belajar dengan hasil belajar pada pokok bahasan persamaan dan pertidaksamaan linier siswa kelas X APK di SMK YPM 3 Taman diterima.

Berdasarkan pengujian hipotesis di atas menunjukkan bahwa ada hubungan antara motivasi belajar dengan hasil belajar pada pokok bahasan persamaan dan pertidaksamaan linier siswa kelas X APK di SMK YPM 3 Taman. maka peneliti menginterpretasikan bahwa semakin tinggi motivasi belajar yang dimiliki siswa maka hasil belajar yang diraih atau dicapai juga akan lebih baik dan sebaliknya semakin rendah motivasi yang dimiliki siswa maka belajar yang diraih semakin rendah. Jadi motivasi menjadi hal yang sangat penting dan harus dimiliki oleh siswa dalam pembelajaran. Hal ini senada dengan pernyataan pentingnya motivasi belajar menurut Nanang dan Cucu (2009:26) dikarenakan:

1. Motivasi merupakan pendorong terjadinya perilaku belajar peserta didik

2. Motivasi merupakan alat untuk mempengaruhi prestasi pesertasi didik.

3. Motivasi merupakan alat untuk memberikan direksi terhadap pencapaian tujuan pembelajaran.

4. Motivasi merupakan alat untuk membangun sistem pembelajaran lebih bermakna.

\section{PENUTUP}

Berdasarkan hasil penelitian tentang hubungan antara motivasi dengan hasil belajar matematika pada pokok bahasan persamaan dan pertidaksamaan linier siswa kelas X APK di SMK YPM 3 Taman hipotesis tersebut dapat diambil kesimpulan sebagai berikut.

\section{Simpulan}

Dari hasil kajian teori dan hipotesis yang diajukan dalam penelitina ini diperoleh hasil $r_{\text {hitung }}=0.379$. Hal 
ini menunjukkan bahwa $r_{\text {hitung }}>r_{\text {tabel }}$ yang artinya Ho ditolak. Jika Ho ditolak maka Ha diterima, yang artinya ada hubungan motivasi belajar dengan hasil belajar pada pokok bahasan persamaan dan pertidaksamaan linier siswa kelas X APK di SMK YPM 3 Taman.

\section{Saran}

Saran-saran penulis terhadap hasil penelitian ini sebagai berikut.

1. Untuk guru, sebagai masukan bahwa motivasi belajar berpengaruh terhadap hasil belajar siswa. Oleh karena itu guru hendaknya memberikan dan membangun motivasi pada diri siswa.

2. Sekolah, motivasi belajar salah satunya diperoleh dari lingkungan belajar, sehingga dalam pembelajaran diperlukan suasana belajar yang kondusif dengan memperhatikan sarana dan prasana yang dimiliki sekolah .

\section{DAFTAR PUSTAKA}

Arikunto, Suharsimi. 2006. Dasar-dasar Evaluasi Pendidikan. Jakarta : Bumi Aksara.

Nanang dan Cucu, 2009. Konsep strategi pembelajaran, Retika Aditama

Sugiyono, 2008. Metode penelitian kuantitati, kualitaatif dan $R \& D$. Bandung : Alfabeta.

Undang-Undang Republik Indonesia Nomor 20 Tahun 2003 Tentang Sistem Pendidikan Nasional.

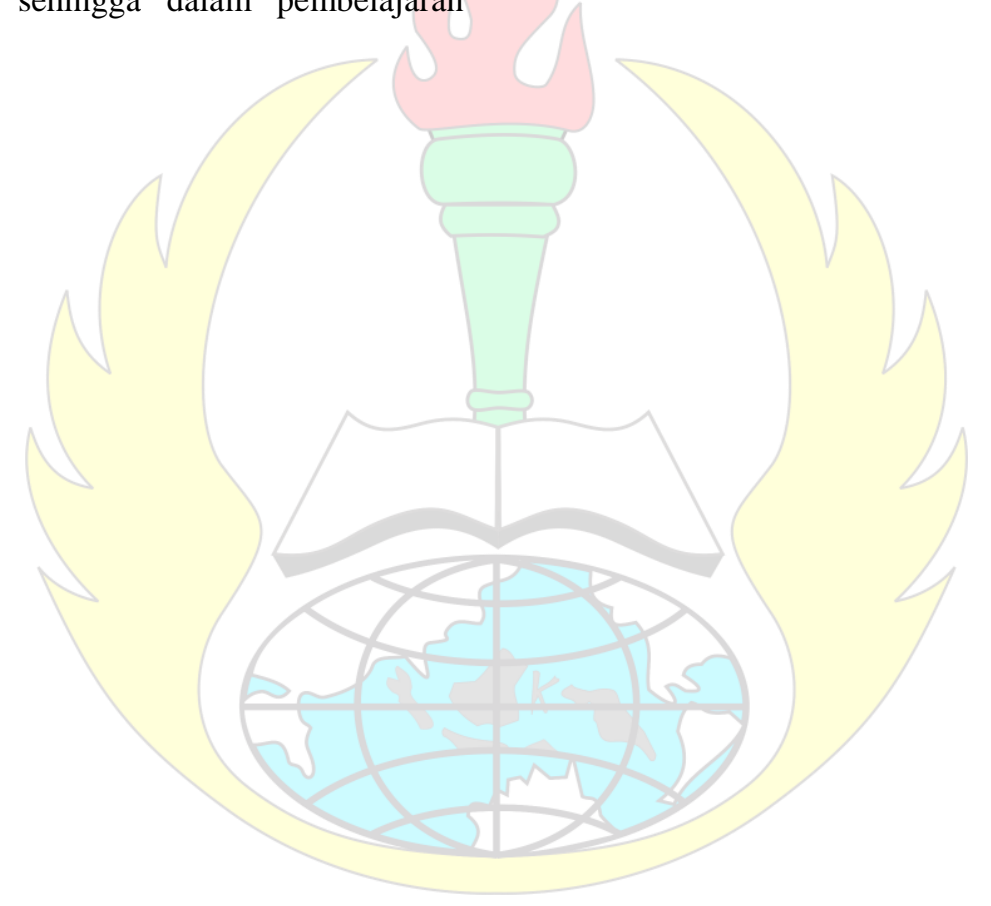

